\section{Weapons physicist 'denied access' to remanufacture data}

[WASHINGTON] The National Security Council intervened to block a study by the Arms Control and Disarmament Agency (ACDA) into the maintenance of the US nuclear weapons stockpile, according to the scientist who had been about to undertake the study.

Ray Kidder, a veteran nuclear weapons designer, was informed last month by ACDA that his help was no longer needed because the Department of Energy (DOE) would not give him access to a 1990 classified study of weapon remanufacture. Kidder believes that access was refused because of his public criticism of the DOE's stockpile stewardship programme - most notably an article in Nature last spring (see Nature 386, 645;1997).

In the article, Kidder questioned the need for the stockpile stewardship programme, which uses supercomputers and major new experimental facilities to simulate nuclear weapons. He proposed a smaller alternative which would maintain the weapons by remanufacturing components as they age.

Carmen MacDougall, deputy assistant secretary for communications, says that the DOE "fully supports the need for ACDA to review the study" and that it gave the agency a technical briefing on its contents. "We offered ACDA the briefing and they accepted it," she says. "The allegations of retribution and revenge are baseless and bizarre."

The issue is sensitive for the US government. President Bill Clinton is trying to win Senate ratification for the Comprehensive Test Ban Treaty this year, on the basis of as broad a coalition of support as possible for the $\$ 4.5$ billion-a-year stockpile stewardship programme.

In November, Pierce Cordon of ACDA wrote to Kidder asking him to work for the agency as a consultant, to help determine "whether the US can be confident of weapons using remanufactured components". Cordon's letter asked Kidder to review the previous, classified study, which DOE conducted for Congress in 1990.

Kidder has the security clearance to access the study, provided he has a "need to know". A request for permission was referred to the office of Vic Reis, assistant secretary at DOE. According to Kidder, Reis could not dispute his need to know, and therefore asked Robert Bell, special assistant to the president at the National Security Council, to press ACDA to stop the study.

"My information is that Bell called ACDA and told them not to allow this to go forward," says Kidder.

But MacDougall denies that Reis asked Bell to block the study.

Colin Macilwain

\title{
Tokyo centre takes steps to boost patent output
}

[TOKYO] A university in Japan is aiming to increase its output of patents by turning to entrepreneurship. Its research centre is to become the country's first university organization to set up a company encouraging researchers to seek both patents on their results and private buyers for the rights to these patents.

Japanese universities, unlike their counterparts in the West, produce very few patents. According to the country's patent office, for example, although 215,400 domestic patents were filed by Japan in 1996, only seven were produced in the same year by Tokyo University.

But now this university is attempting to alter the situation. Professors from its Research Centre for Advanced Science and Technologsy (RCAST) have set up the Intellectual Property Company. It will be staffed by the university's postgraduate students and by staff recruited from outside. The director, too, will be appointed from outside - possibly from one of the national banks.

The company will help to evaluate the marketability and patentability of inventions made by researchers from the research centre, which specializes in areas such as biotechnology, materials science and electronics. The company will then draft patent applications and help researchers to sell the patents to industry. The last of these tasks will be carried out either directly or through intermediate agents acting for both domestic and international companies. If the sales are successful, the intermediate agents will be paid a commission. Between five and ten per cent of the proceeds from patent rights will go to the inventor, and the rest will be paid into RCAST's research budget.

Some Japanese universities have already strengthened their links with industry to promote the commercial exploitation of their inventions. Those that have already set up

university/industry liaison offices include Tsukuba University, Ritsumeikan University and Tokyo University itself. "Commercial application of research could potentially be the key to revive the Japanese economy," says one official from the Ministry of International Trade and Industry.

Until now, however, the rights to most patentable discoveries and inventions made in universities have been transferred to industry in exchange for a 'refund' of the research costs to the inventor.

Isao Karube, professor in bioelectronics and biotechnology at RCAST, and one of the founder members of the Intellectual Property Company, has invented many products, including a biosensor for O-157 E. coli. Although his research efforts have produced more than 300 potentially patentable inventions, Karube has assigned most of them to private companies for patent application.

Obtaining patents, he says, adds nothing to the status of Japanese scientists; producing scientific papers is regarded as more important. "We never have the time to file applications for patents; we often give [inventions and discoveries] away to companies."

Etsuo Niki, director of RCAST, hopes that the Intellectual Property Company will change such attitudes, as it will recruit professional staff to apply for patents. The company will also provide an opportunity for overseas companies to gain access to Japanese technology, which has long been considered inaccessible to industry outside the country, he says. "In fact, the first company to access us could well be a non-Japanese company; we are receiving a huge response from abroad," says Karube.

Others point out that, for new ventures such as Tokyo University's company to succeed, those involved have to demonstrate an entrepreneurial spirit, which is rare in Japanese universities.

AsakoSaegusa

\section{Stamp marks Max Planck milestone}

[MUNICH] This special stamp marks the fiftieth anniversary of Germany's basic research organization. Issued last week, the stamp shows founding members of the Max Planck Society (MPS) with computer-coded images representing some of the scientific advances they pioneered: an X-ray picture of the Moon, an ion trap and a goldfish nerve.

The society was founded in 1948, despite resistance at the time from the United States to the post-fascist Germany being allowed to undertake research. It succeded the Kaiser Wilhelm Society — itself founded in 1911

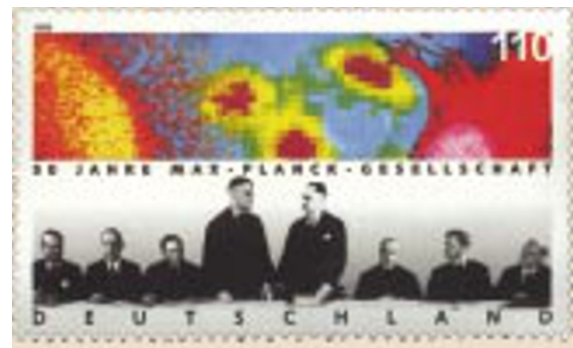

but discredited and eventually closed because of its participation in the nationalist aims of the Nazis.

Burkhardt Roeper 